\title{
КОМПЕТЕНЦІЇ МЕДИЧНОЇ СЕСТРИ В ДОГЛЯДІ ЗА ХВОРИМИ ГЕПАТОЛОГІЧНОГО ПРОФІЛЮ
}

\author{
Д. С. Дунда, О. В. Прокопчук, С. В. Даньчак \\ Тернопільський національний медичний університет \\ імені І. Я. Горбачевського МОЗ Украӥни
}

У статті висвітлено сучасні дані щодо професійної компетентності та професійної мобільності молодшого медичного персоналу при догляді за пацієнтами із захворюваннями печінки в сучасних умовах, маніпуляції, які використовують у даній професії, та специфіку їх проведення. Розвиток системи професійної підготовки медичних працівників є важливим питанням сьогодення та вимагає перегляду 3 метою удосконалення сестринської справи.

\section{NURSE'S COMPETENCE IN CARE OF PATIENTS WITH HEPATIC DISORDERS}

\author{
D. S. Dunda, O. V. Prokopchuk, S. V. Danchak \\ I. Horbachevsky Ternopil National Medical University
}

The article presents current data on professional qualities of a nurse in care of patients with hepatic disorders nowadays and manipulations used in the profession and the specifics of their conduct. The development of the training system for health care professionals is an important issue today and requires review for the purpose of improving nursing.

Вступ. Концепція Міністерства охорони здоров'я має чіткі вимоги до розвитку системи професійної підготовки медичних кадрів. Сестринська справа $\epsilon$ важливою складовою кадрового ресурсу медичних працівників. Ефективний розвиток системи охорони здоров'я значною мірою залежить від стану професійної підготовки медичних сестер як найбільш об'ємної складової кадрового ресурсу [3].

Основними системотворчими поняттями підготовки медичних сестер у безперервному професійному навчанні $\epsilon$ «професійна компетентність» та «професійна мобільність медичної сестри» [5].

Проблемам вищезгаданих термінів присвячено безліч робіт та досліджень. Однак попри це єдиного визначення вони не мають. Аналіз контенту певних робіт та обов'язків медичних сестер дає можливість визначити та виділити певні ознаки компетентності. До них можна віднести знання та вміння, що необхідні для продуктивної діяльності, а також готовність особистості до певного виду діяльності. Саме ці аспекти безпосередньо відображаються у роботі медичних сестер, які доглядають за пацієнтами гепатологічного профілю [7].

(․ Д. С. Дунда, О. В. Прокопчук, С. В. Даньчак, 2020
Основна частина. Комітет експертів ВООЗ ще в 60-ті роки чітко визначив сестринську справу як «практику людських взаємовідносин», але попри це також чітко окреслює функціональні обов'язки: «Сестринська справа - це складова частина системи охорони здоров'я, яка направлена на вирішення проблем індивідуального та громадського здоров'я населення в мінливих умовах навколишнього середовища. Сестринська справа включає діяльність зі зміцнення здоров'я, профілактики захворювань, надання психосоціальної допомоги особам, які мають фізичні та (або) психічні захворювання, а також непрацездатним всіх вікових груп» [1].

Сестринський процес $є$ основою безпосередньої сестринської справи. Для його виконання медична сестра повинна володіти основами терапії, у разі догляду за пацієнтами з захворюваннями печінки основами гематології, вміти застосовувати практичні вміння, знати основи клінічної фармакології. Це сприяє підвищенню професіоналізму і компетентності в практичній діяльності [8].

В основі сестринського догляду за пацієнтами гепатологічного профілю $є$ визначені положення на основі теорії та практики. Відтак при обстеженні

12 ISSN 2411-1597. МЕДСЕСТРИНСТВО. 2020. № 2 
пацієнтів із захворюваннями печінки потрібно враховувати всі характерні скарги: локалізація болю, іррадіація, інтенсивність, час виникнення (зв'язок із прийомом їжі), диспепсичні явища, наявність проносу, закрепу, слизу і крові, здуття живота [6].

Медична сестра повинна звернути увагу на перенесені захворювання, умови побуту і праці, шкідливі звички хворого, також потрібно враховувати спадковість хворого.

При огляді необхідно брати до уваги положення хворого в ліжку, стан ротової порожнини, колір шкірних покривів, наявність печінкових ознак, наприклад судинних зірочок, розміри та форму живота, вираженість судинного малюнку [6].

Медична сестра бере безпосередню участь в підготовці хворих до різних обстежень, повинна вміти робити промивання шлунка, постановку різних видів клізм, зібрати кал для дослідження. В обов'язки медичної сестри також входить заповнення медичної документації, при необхідності - супровід хворих до місця обстеження.

Серед інструментальних методів обстежень у молодшого медичного персоналу теж $є$ частина маніпуляцій, які вони виконують. Медична сестра повинна вміти правильно зробити забір шлункового і дуоденального вмісту. При цій процедурі хворого необхідно заспокоїти, пояснити мету процедури, можливі ефекти [6].

Рентгеноскопію шлунка проводять натщесерце, медична сестра повинна простежити аби хворий до дослідження не пив воду, не приймав ліки, не курив.

До холецистографічного обстеження хворого готують відповідним чином: за 2 доби призначають безшлакову дієту, напередодні ввечері після легкої вечері ставлять очисну клізму. Контрастну речовину беруть двома порціями: першу порцію дають хворому за 12 год до дослідження, другу - за 4 год [4].

\section{СПИСОК ЛІТЕРАТУРИ}

1. Безкоровайна У. Ю. Порівняльний аналіз ролі медичної сестри в Україні та у світі / У. Ю. Безкоровайна // Інвестиції: практика та досвід. - 2016. - № 15. - С. 88-91.

2. Кузмінська І. В. Медсестринство як впливова самостійна ланка медицини / І. В. Кузмінська, І. М. Круковська // Медсестринство. - 2009. - № 2. - С. 28-30.

3. Міністерство охорони здоров'я України [Електронний ресурс]. - Режим доступу : http://www.moz.gov.ua/ ua/portal/.

4. Ильченко А. А. Болезни желчного пузыря и желчных путей / А. А. Ильченко. - М. : МИА, 2011.
Перед гастродуоденоскопією хворому напередодні ввечері можна їсти не пізніше 20 год, вранці забороняється вживання води, їжі, куріння.

При підготовці до колоноскопії за три доби до дослідження хворому призначають безшлакову дієту, напередодні о 15 год дають 50 мл касторової олії, ввечері в 20 год і вранці в день дослідження ставлять очисні клізми.

За виконанням всіх рекомендацій стежить медичний персонал. Важливо розуміти, що $є$ певна когорта пацієнтів, які мають особливі потреби у догляді, наприклад ті, в яких є колостома, при наявності якої відбувається неконтрольоване виділення калу в спеціальну ємність - калоприймач. Такі хворі найчастіше зазнають труднощів психологічного характеру, які пов'язані зі справлянням фізіологічних потреб. Медична сестра повинна допомогти вирішити проблеми хворого, навчити поводитися з калоприймачем та ознайомити зі способами догляду за стомою [5].

Вищевказані маніпуляції є далеко не єдиними у своєму роді серед чисельних опцій медичних сестер. Можна зрозуміти, що таких прикладів можна навести сотні. Саме це дає змогу осягнути всю відповідальність, яка вкладена у цю професію.

Висновки. Розвиток системи професійної підготовки медичних працівників є важливим питанням сьогодення. Робота молодшого медичного персоналу часто $\epsilon$ недооціненою за рахунок відсутності розуміння всього об'єму обов'язків та компетенцій, які покладені в основу цієї професії. Важливим у роботі $є$ не лише вміння виконувати маніпуляції, але й застосування знань психоемоційної сфери. Без цих двох складових медсестринська допомога $\epsilon$ неможливою. Попри це має бути перегляд всієї системи підготовки фахівців сестринської справи з впровадженням нових технологій організації медсестринської допомоги, а також матеріальної та правової підтримки медичних сестер.

5. Болезни печени и желчевыводящих путей : руководство для врачей / Под ред. В. Т. Ивашкина. - 2-е изд. М. : Изд. дом «М-Вести», 2012. - 536 с.

6. Корягина Н. Ю. Организация специализированного сестринского ухода / Н. Ю. Корягина, Н. В. Широкова. М. : ГЭОТАР-Медия, 2009. - 464 с.

7. Равен Дж. Компетентность в современном обществе: выявление, развитие и реализация / Дж. Равен. - М. : «Когито-Центр», 2002. - 396 с.

8. Patterson E. Primary health care and general practice nurses: what is the nexus? / E. Patterson, K. Price, D. Hegney.

Отримано 20.02.20 